Research Article

\title{
EFFECT OF PACLOBUTRAZOL ON OFF-SEASON FLOWER INDUCTION IN ACID LIME (Citrus aurantifolia Swingle) LANDRACES UNDER CHITWAN CONDITION
}

\author{
K. M. Tripathi and D. D. Dhakal \\ Institute of Agriculture and Animal Sciences, Rampur, Chitwan, Nepal
}

\begin{abstract}
The experiment was conducted to assess the effectiveness of paclobutrazol in inducing off-season flowering in two Nepalese and one Indian commercial landraces of acid lime during 2002 to 2003 at Rampur, Chitwan, Nepal. The experiment was laid out in split-plot design with landraces as main plot and dates of application of paclobutrazol as sub plot factors. Fourteen month-old seedlings of landraces planted on 28 May 2001 were soil drenched with paclobutrazol (25\%)@ $5 \mathrm{ml}$ per tree at the collar region of the tree on four different dates at 50 days interval beginning from 17 July to 17 December, 2002. Paclobutrazol applied on 17 July was the most effective in inducing early flowering at fourth week of December, which was 70 days ahead of normal flowering date. The subsequent applications on September, October and December also advanced flowering time by 59, 41 and 32 days, respectively. The earlier (July) application of paclobutrazol was superior among the treatments under Chitwan condition to induce and advance early flowering for offseason market.
\end{abstract}

Key words: Cultar, sourlime, germplasm

\section{INTRODUCTION}

Acid lime (Citrus aurentifolia Swingle) is the popular citrus fruit crop of Nepal. It is grown in the marginal lands in the mid hills of the country. The fruits have long post harvest life and can withstand rough handling during marketing. It occupies about 3747 ha with a production of over 16 thousand $\mathrm{mt}$ (HMG, 2001/02). It is used as juice, deserts, pickle, part of green salad, lemon tea or hot lemon and raw materials for processing industries and Ayurvedic medicines. Nepal has a large pool of genetic resources of lime (Dhakal et al., 2002), but there is a wide gap between demands and production of acid lime in the country. Domestic lime contributes only 9 percent of the total supplies in the major market centers during the season in the country. Almost all offseason limes marketed in Nepal are imported from India. An annual import of fresh lime fruits from India was $2110 \mathrm{mt}$ valued at NRs 60 million (Dhakal et al., 2003).

Breaking the seasonality of acid lime for commercial production would not only substitute the import of fresh fruits, but also provide the incentive prices to the lime growers. Off season production of lime to catch off-season market is being practiced in India (Rajput and Haribabu, 1991; and Bal, 1997). Withholding water, root exposure and root pruning are the common practices adopted to regulate flowering (Bajwa and Bal, 1984). In the recent years, paclobutrazol, a growth retardant has been used with considerable success to induce early flowering for off-season production in several fruit crops such as apple (Tromp, 1987), peach (Martin et al., 1987), mango (Karki, 2000) and citrus (Bausher and Yelenosky, 1986; Dhakal and Guzman, 1992; Snowball et al.,1994). Therefore, the present study was undertaken to determine the effectiveness of paclobutrazol and its date of application in inducing flowering for off-season production of acid lime landraces under Rampur conditions.

\section{MATERIALS AND METHODS}

A field investigation was carried out to assess the effectiveness of paclobutrazol in inducing off-season flowering at the Institute of Agriculture and Animal Sciences (IAAS), Rampur, Chitwan Nepal in 2002/03. Fourteen-month-old trees of three Accessions of landraces: Jhapa (Accession \# 7), Madras (Accession \# 75) and Darchula (Accession \# 76) planted on 28 May 2001 were used as experimental plants. The trees were uniform in age and size and trained to single stem. The trees were grown under rain-fed condition following common cultural practices during the study period. Five $\mathrm{ml}$ of paclobutrazol dissolved in one liter of water was applied at collar region of the trees on four different dates at 50 days interval beginning from 17 July to 17 
December 2002. The experiment was laid out in split plot design with landraces as main-plot and date of paclobutrazol application as sub-plot factors. Observations were recorded on time taken to first flower, number of flowering shoot, fruit set, and subsequent phases of flowering.

\section{RESULTS AND DISCUSSION}

\section{Days to flowering}

Effect of dates of paclobutrazol application on days to first flower in different acid lime landraces is presented in Table 1 . The data show that all the dates of application were significantly effective in inducing early flowering in acid lime landraces. The treatments advanced the flowering by 32 to 70 days from normal season. The July application advanced the flowering by 70 days followed by September (59 days), October (41 days) and December 32 (days), respectively. Although the effects of all dates of application were significantly different from each other, July treatment was the most effective in advancing flowering (Fig. 1). The flowering commenced from the fourth week of December in trees treated on 17 July followed by the second week of January when treated on 5 September. Similarly, flowering began from the fourth week of January and the first week of February when treated on 27 October and 17 December, respectively (Fig. 1). In control trees, flowering started only after the third week of March, which was normal flowering season of lime under Chitwan condition. Similarly, there were significant responses among the three landraces to paclobutrazol application. Accession 75 flowered significantly earlier than Accessions 7 and 76. The interaction effect between landraces and treatment was also significant $(\mathrm{P}<0.01)$.

Table 1. Effect of dates of paclobutrazol application on time taken to first flowering in acid lime landraces, Rampur, 2002/03

\begin{tabular}{|lllll|}
\hline \multirow{2}{*}{ Date of application } & \multicolumn{4}{c|}{ Days taken to first flower } \\
\cline { 2 - 5 } & Accession 7 & Accession $\mathbf{7 5}$ & Accession 76 & Mean \\
\hline July 17 & $173(67) \mathrm{h}$ & $166(76) \mathrm{i}$ & $182(66) \mathrm{g}$ & $173.7(70) \mathrm{e}$ \\
Sept.5 & $182(58) \mathrm{g}$ & $174(68) \mathrm{h}$ & $197(51) \mathrm{f}$ & $184.3(59) \mathrm{d}$ \\
Oct.27 & $202(38) \mathrm{e}$ & $197(45) \mathrm{f}$ & $209(39) \mathrm{d}$ & $202.7(41) \mathrm{c}$ \\
Dec.17 & $209(31) \mathrm{d}$ & $206(36) \mathrm{d}$ & $218(30) \mathrm{c}$ & $211.2(32) \mathrm{b}$ \\
Control & $240 \mathrm{~b}$ & $242 \mathrm{~b}$ & $248 \mathrm{a}$ & $243.3 \mathrm{a}$ \\
Mean & $201.2 \mathrm{~b}$ & $197.1 \mathrm{c}$ & $210.8 \mathrm{a}$ & \\
\hline
\end{tabular}

Same letter (s) within the column and row are not significantly different at $\mathrm{P}=0.05$ by DMRT; Figures in parenthesis are days advanced in flowering from normal flowering season; $\mathrm{L}=$ Landrace, $\mathrm{T}=$ Treatments, $\mathrm{ns}=$ non significant $(\mathrm{P} \geq 0.05)$

The present findings agree with the works of Snowball et al. (1994) who found that 'West Indian' acid lime and 'Meiwa' kumquat seedlings treated with paclobutrazol flowered three months earlier than untreated trees. They found flowering within 11 months from germination, whereas plants without paclobutrazol treatment did not flower until they were14 months old.

\begin{tabular}{|c|c|c|c|c|c|c|c|c|c|c|c|c|c|c|c|}
\hline Treatment & Dec & & & & & & & & & ary & & & & & \\
\hline Week & 2 & 3 & 4 & 1 & 2 & 3 & 4 & 1 & 2 & 3 & 4 & 1 & 2 & 3 & 4 \\
\hline July 17 & 70 days early & & & & & & & & & & & & & & \\
\hline Sept5 & 59 days early & & & & & & & & & & & & & & \\
\hline Oct.27 & 41 days early & & & & & & & & & & & & & & \\
\hline Dec.17 & 32 days early & & & & & & & & & & & & & & \\
\hline Control & & & & & & & & & & & & & & & \\
\hline
\end{tabular}

Figure 1. Flowering time (week) as influenced by dates of paclobutrazol treatment in acid lime landraces, Rampur 2002/03

In a similar study, Dhakal and Guzman, (1992) obtained 100 percent flowering within 30 days of paclobutrazol treatment in calamondin (Citrus medurensis). Several other workers also reported that paclobutrazol induced or enhanced flowering in citrus (Bausher and Yelenosky, 1986), kumquat citrus (Iwahori and Tominaga, 1986), mango (Karki, 2000), peach (Martin et al., 1987), pecan (Andersen and Aldrich, 1987), and apple (Tromp, 1987). 


\section{Days to anthesis}

Effect of dates of paclobutrazol application on time (days) taken to anthesis after emergence of flower buds of three Accessions of acid lime landraces is presented in Table 2. Dates of paclobutrazol application significantly affected the time taken to anthesis of flower buds after the emergence of flower buds. Both dates of application and landraces were found significant $(\mathrm{P}<0.01)$ but interaction between them was insignificant.

Among the landraces, Accession 76 opened flower significantly earlier (20.53 days) than Accession 75 (25.87 days) and Accession 7 (27.47 days). But the difference in time taken for anthesis in Accession 75 and Accession 7 was at par. The effect of 17 July and 5 September application was also at par but both were significantly superior to October and December applications. The shortest time was recorded in control trees (10 days) followed by the trees treated on 17 December (18 days) and a maximum days in the trees treated on 17 July (37 days). All the date of application was significantly different from control. Numbers of flower bud emergence in the trees treated with paclobutrazol was just before the onset of cold months whereas flower bud emergence in control trees was after cold months.

Table 2. Effect of dates of paclobutrazol application on time taken to anthesis after emergence of flower buds (days) in acid lime landraces, Rampur 2002/03

\begin{tabular}{|lllll|}
\hline \multirow{2}{*}{ Date of application } & \multicolumn{4}{c|}{ Time taken to anthesis } \\
\cline { 2 - 5 } & Accession 7 & Accession 75 & Accession 76 & Mean \\
\hline July 17 & 35.3 & 42.3 & 30.0 & $37.0 \mathrm{a}$ \\
Sep5 & 42.3 & 36.7 & 33.3 & $34.7 \mathrm{a}$ \\
Oct.27 & 26.0 & 23.7 & 25.0 & $23.0 \mathrm{~b}$ \\
Dec.17 & 23.0 & 16.0 & 19.3 & $18.0 \mathrm{~b}$ \\
Control & 10.7 & 10.7 & 10.0 & $10.14 \mathrm{c}$ \\
Mean & $27.5 \mathrm{a}$ & $25.9 \mathrm{a}$ & $20.5 \mathrm{~b}$ & 24.6 \\
\hline
\end{tabular}

$\mathrm{L}=$ Landrace, $\mathrm{T}=$ Treatments, $\mathrm{ns}=$ non significant $(\mathrm{P}>0.05)$ Same letter $(\mathrm{s})$ within the column and row are not significantly different at $\mathrm{P} \leq 0.05$ by DMRT

The low temperature during the cold month attributed to delay in anthesis process of flowers in the treated trees where bud appearance was before or during cold months. The control tree showed short time for anthesis because control tree induced flower after winter when the temperature was already high.

The finding of this investigation agrees with the work done by Pharis and King (1985) who found date and duration of bloom highly variable even in the same landrace. They found the differences of up to 40 days in the commencement of anthesis. Similarly, slightly climatic differences between locations also affected the date of bloom.

\section{Number of flower shoots}

Effect of date of paclobutrazol application on number of flower shoot per plant of acid lime landraces is presented in Table 3. All dates of application increased the numbers of flower shoots significantly over control. But the mean differences of dates of application were not significantly different from each other.

However, Paclobutrazol applied on 27 October produced the highest number of flower shoots (13.3) followed by 5 September (11.4), whereas control tree produced the minimum number of flower shoots (3.3). Similarly, Accession 76 produced maximum numbers of shoots (12.8/tree) followed by Accessions 75 and 7. Accession 76 as control produced the minimum (1.33) numbers of flowering shoots. Accession 76 was the most sensitive to paclobutrazol application.

Paclobutrazol applied on 27 October produced maximum flower shoots (23) in Accession 76 followed by 17 December (16.7), whereas the 17 July application produced the maximum flower shoots (15.7) in Accession 75 followed by September application. The interaction effect between landraces and date of paclobutrazol application was significant $(\mathrm{P}<0.01)$. This finding is also supported by the work of Karki (2000), who found paclobutrazol to induce the highest number of flowers per panicle in mango under Chitwan condition. Several other workers also observed that soil applied paclobutrazol significantly increased number of flowers in citrus (Dhakal and Guzman, 1992) and ornamental plants (Wilkinson and Richards, 1987). 
Table 3. Effect of date of paclobutrazol application on number of flower shoots per plant in acid lime landraces, Rampur 2002/03

\begin{tabular}{|lllll|}
\hline \multirow{2}{*}{ Date of application } & \multicolumn{4}{c|}{ Numbers of flower shoot per plant } \\
\cline { 2 - 5 } & Accession 7 & Accession $\mathbf{7 5}$ & Accession $\mathbf{7 6}$ & Mean \\
\hline July 17 & $5.0 \mathrm{ef}$ & $15.7 \mathrm{bc}$ & $11.3 \mathrm{bcde}$ & $10.7 \mathrm{a}$ \\
Sep5 & $8.3 \mathrm{cdef}$ & $14.3 \mathrm{bcd}$ & $11.7 \mathrm{bcde}$ & $11.4 \mathrm{a}$ \\
Oct.27 & $6.7 \mathrm{def}$ & $10.3 \mathrm{bcdef}$ & $23.0 \mathrm{a}$ & $13.3 \mathrm{a}$ \\
Dec.17 & $8.0 \mathrm{cdef}$ & $9.0 \mathrm{f}$ & $16.7 \mathrm{ab}$ & $11.2 \mathrm{a}$ \\
Control & $2.3 \mathrm{f}$ & $6.3 \mathrm{ef}$ & $1.3 \mathrm{i}$ & $3.3 \mathrm{~b}$ \\
Mean & 6.1 & 11.1 & 12.8 & 10.0 \\
\hline
\end{tabular}

$\mathrm{L}=$ Landrace, $\mathrm{T}=$ Treatments, $\mathrm{ns}=$ non significant $(\mathrm{P}>0.05)$, Same letter $(\mathrm{s})$ within the column and row are not significantly different at $\mathrm{P} \leq 0.05$ by DMRT

\section{Fruit set}

Effects of dates of paclobutrazol application on fruit set per plant (scoring 1-3) in acid lime landraces are presented in Table 4. All dates of application increased fruit set significantly over control and the effects within the treatments were at par. Though insignificant, October treatment had more numbers of fruit set followed by December treatment. Similarly, the fruit set though insignificant was higher in Accession 76 (1.9) followed by Accessions 75 (1.8) and 7 (1.3). The interaction between dates of application and landraces was also insignificant. The present findings are in agreement with the works of several workers.

Table 4. Effect of dates of Paclobutrazol application on fruit set per plant (score scale 1-3) in acid lime landraces, Rampur 2002/03

\begin{tabular}{|lllll|}
\hline \multirow{3}{*}{ Date of application } & \multicolumn{3}{c|}{ Fruit set per plant } \\
\cline { 2 - 5 } & Accession 7 & Accession 75 & Accession 76 & Mean \\
\hline July 17 & 0.67 & 2.67 & 2.33 & $1.88 \mathrm{a}$ \\
Sep5 & 2.0 & 1.67 & 1.67 & $1.77 \mathrm{a}$ \\
Oct.27 & 1.67 & 1.33 & 3.00 & $2.00 \mathrm{a}$ \\
Dec.17 & 2.0 & 2.0 & 2.33 & $0.66 \mathrm{~b}$ \\
Control & 0.33 & 1.33 & 0.33 & 1.93 \\
Mean & 1.33 & 1.80 & . & \\
\hline
\end{tabular}

$\mathrm{L}=$ Landrace, $\mathrm{T}=$ Treatments, $\mathrm{ns}=$ non significant $(\mathrm{P}>0.05)$, Same letter $(\mathrm{s})$ within the column and row are not significantly different at $\mathrm{P} \leq 0.05$ by DMRT

Paclobutrazol stimulated flower bud initiation, enhanced fruit set in apple (Greene, 1986), grape (Shaltout et al., 1988) and mango (Goguey, 1990). Similarly, soil drench of paclobutrazol $5 \mathrm{ml}$ or above induced $66 \%$ fruit set in citrus (Dhakal and Guzman, 1992).

\section{Second phase of flowering}

Effect of date of paclobutrazol application on second phase of flowering per plant (scoring 1-3) of acid lime landraces is given in Fig. 2. Date of paclobutrazol application significantly $(\mathrm{P}<0.01)$ induced second phase of flowering. The last date of application (17 December) that produced maximum number of flowers in all landraces was significantly superior to the rest of the treatments. The flower numbers of earlier three dates were not significantly different from each other. The varietal difference was not significant from each other. However, the 5 September application produced remarkably second flush of flowers only in Accession 75 . The interaction between landraces and dates of application was also insignificant.

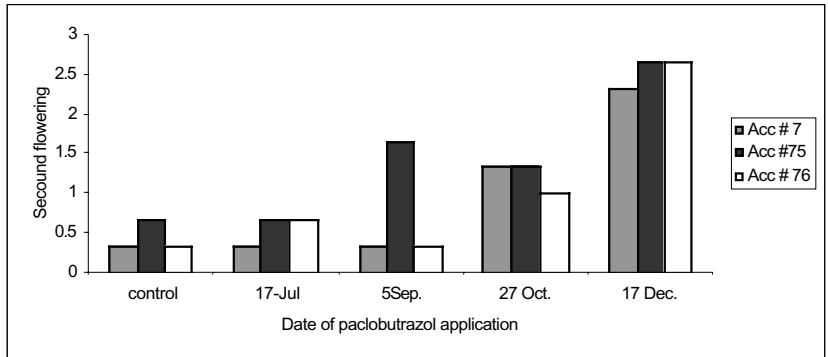

Figure 2. Effect of dates of paclobutrazol application on second phase of flowering (scoring 1-3 scale) in acid lime landraces, Rampur 2002/03 
Endogenous gibberellins act like exogenous gibberellins, as inhibitors of flowering; so applications of gibberellins-biosynthesis inhibitors enhance the flowering of citrus. Woody tree below critical level of gibberellins induced flowering but trees above critical level of gibberellins suppress the flowering (Dhakal and Guzman, 1992). Paclobutrazol inhibits GA biosynthesis by blocking especially the steps in the oxidation of ent-kaurene to ent-kaurenoic acid. It mainly inhibits the function of kaurene synthetase (Sterrett, 1985; Dalziel, 1984). Therefore, flower induction in woody fruits including acid lime may be attributed to the reduced level of gibberellins below critical level for flowering.

\section{CONCLUSIONS}

It is technically feasible to advance the flowering more than two months from normal season in acid lime landraces under Chitwan condition, which would eventually advance the harvest time of lime to address the off-season market. Time of paclobutrazol application is very important and critical for off-season production. An application made during different portion of the growing season might produce different responses. The early dates of paclobutrazol application were the most effective in inducing off-season flowering than later dates. However, further research is suggested to standardize the date of application to produce the lime at desired time to address the off-season markets.

\section{ACKNOWLEDGEMENTS}

The authors highly appreciated the Institute of Agriculture and Animal science Rampur Nepal and Hill Agricultural Research Project (HARP project 39/00) for facilitating the financial support and field experiments.

\section{REFERENCES CITED}

Andersen, P. C. and J. H. Aldrich. 1987. Effect of soil applied paclobutrazol on "Cheyenne".

Bajwa, G. S. and J. S. Bal. 1984. Citriculture Manual. Department of Horticulture. P.A.U. Ludhiana, India.

Bal, J. S. 1997. Fruit Growing. Kalyani Publisher, New Delhi, India.

Bausher, M. G. and G. Yelenosky. 1986. Sensitivity of potted citrus plants to top sprays and soil application of paclobutrazol. HortSci. 21 (1): 141-143.

Dalziel, J. B. 1984. Biochemical and biological effect of caurine oxidase inhibitors, such as paclobutrazol. In: R. Mehnett and D.K. Lawrence (eds.) Biochemical Aspects of Synthetic and Naturally Occurring Plant Growth Regulators. British Plant Growth Regulate Group.11:43-57.

Dhakal, D. D. and C. C. deGuzman. 1992. Effect of foliar and soil application of paclobutrazol on growth and flowering of Calamondin (C. madurensis) trees. J. Int. Agri and Ani. Sci. 13: 99-102.

Dhakal, D. D., T. P. Gotame, S. Bhattarai and H. N. Bhandari. 2002. Assessment of lime and lemon production in Nepal. J. Inst. Agric. Anim. Sci., 23: 49-58.

Dhakal, D. D., S. Bhattarai, H. N. Bhandari and. R. C. Bastakoti. 2003. Marketing systems of lime and lemon in Nepal. IAAS/ HART, Technical Paper. T. U. IAAS, Rampur, Nepal.

Goguey, T. 1990. The effect of repeated application of cultar (paclobutrazol) to Mangifera indica L.var. Valancia. Fruit-Paris. 45(6): 599-607.

Greene, D. W. 1986. Effect of paclobutrazol and analogs on growth, yield, fruit quality and storage potential of delicious apple. J. Amer. Soc. Hort. Sci. 111 (3): 328-332.

HMG. 2001/02. Annual report. Fruit Development Division, DOA, HMG/N Kritipur, Nepal.

Iwahori, S. and S. Tominaga. 1986. Increases in first flush flowering of 'Meiwa' kumquat, Fortunella crassifolia swingle, trees by paclobutrazol. Scientia Hort.. 28:347-353.

Karki, K. B. 2000. Effect of Paclobutrazol on off year induction of flowering in mango. MS Thesis, TU. Institute of Agriculture and Animal Sciences, Rampur, Nepal.

Martin, G. C., F. Yoshikawa and J. H. Larue. 1987. Effect of soil application of paclobutrazol on vegetative growth, pruning time, flowering, yield and quality of 'Flavorcrest" peach. J. Amer. Soc. Hort. Sci. 112 (6): 915-921.

Pharis, R. P. and King, R. W. 1985. Gibberellins and reproductive development in seeds plant. Ann. Rev. Plant Physol. 36: 517-68. 
Rajput, C. B. S. and R. S. Haribabu. 1991. Citriculture. Kalyani Publisher, New Delhi, India.

Shaltout, A. D., A. T. Salem and A. S. Kilany.1988. Effect of pre-bloom sprays and soil drenches of paclobutrazol on growth, yield and fruit composition of Roumi Red' grapes. J. Amer. Soc. Hort. Sci. 113 (1): 13-17.

Snowball, A. M., I. J. Warrington, E. A. Halligan and M. G. Mullins. 1994. Phase change in citrus-the effects of main stem node number, branch habit and paclobutrazol application on flowering in citrus seedlings. J. Hort. Sci. 69 (1): 149-160.

Sterrett, J. P. 1985. Paclobutrazol: A promising growth inhibitor for injection into woody plants. J. Amer. Soc. Hort. Sci. 110 (1): 4-8.

Tromp, J. 1987. Growth and flower bud formation in apple is affected by paclobutrazol, daminozide and tree orientation in combination with various gibberellins. J. Hort. Sci. 18: 212-214.

Wilkinson, R. I and D. Richards. 1988. Influence of paclobutrazol on the growth and flowering of Camellia $x$ Williamsii. Hort. Sci. 23 (2): 359-360. 